A-rkivoc

Free to Authors and Readers
A Platinum Open Access Journal

for Organic Chemistry
Review

Arkivoc 2021, part ix, 218-239

\title{
Synthesis of bacterial 2-alkyl-4(1H)-quinolone derivatives
}

\author{
Thi Hong Nhung Nguyen, Dávid Szamosvári, and Thomas Böttcher
}

Department of Chemistry, Konstanz Research School Chemical Biology, Zukunftskolleg, University of Konstanz, 78457 Konstanz, Germany

Faculty of Chemistry, Institute of Biological Chemistry and Centre for Microbiology and Environmental Systems Science, University of Vienna, 1090 Vienna, Austria

Email: thomas.boettcher@univie.ac.at

\section{Dedicated to Professor Jan Bergman on the occasion of his $80^{\text {th }}$ birthday}

Received 04-30-2021

Accepted 08-12-2021

Published on line 11-12-2021

\section{Abstract}

The compound class of 2-alkyl-4(1H)-quinolones represents a unique group of bacterial secondary metabolites that have been the subject of extensive research since their first discovery over 70 years ago. New insights into their structural diversity and their role in the complex interactions in bacterial ecology and human pathogenicity are still being discovered. In parallel with the ongoing discovery of new 2-alkyl-4(1H)-quinolones and derivatives produced by microbes, synthetic methods were developed to facilitate access to these structurally diverse bioactive compounds. Here we present a detailed overview of the historical development and recent advances in their chemical synthesis.

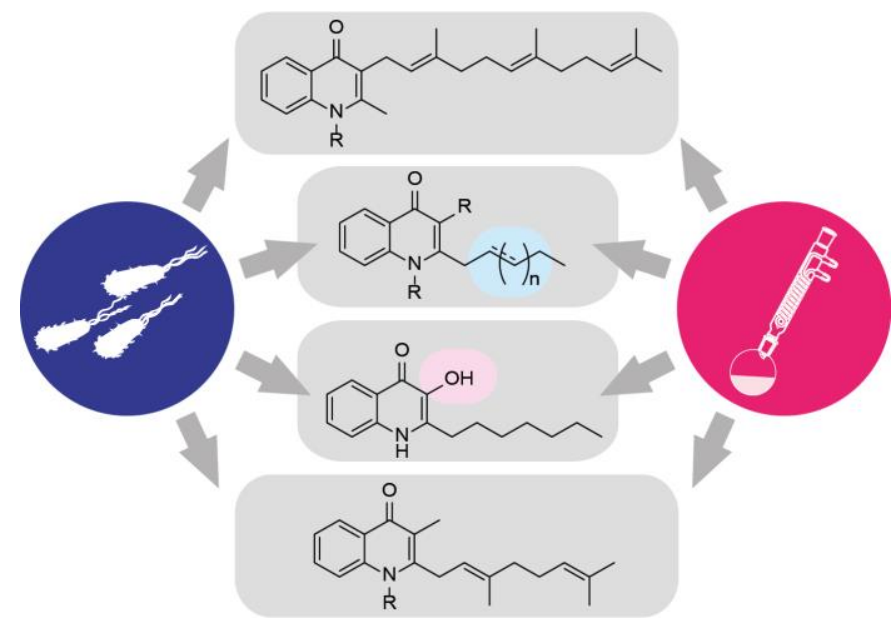

Keywords: Quinolones, quorum sensing, AQNOs, Pseudomonas, Burkholderia 


\section{Table of Contents}

1. Introduction

2. Natural Diversity of 2-Alkyl-4(1H)-quinolones

3. Synthetic Strategies

3.1. Synthesis of quinolone derivatives of Pseudomonas aeruginosa

3.1.1. Synthesis of 2-alkyl-4(1H)-quinolone congeners

3.1.2. Synthesis of unsaturated and unusual 2-alkyl-4(1H)-quinolone congeners

3.1.3. Synthesis of the Pseudomonas Quinolone Signal (PQS)

3.1.4. Synthesis of 2-Alkyl-4(1H)-quinolone $N$-oxides

3.2. Synthesis of MAQs and MAQNOs of Burkholderia

3.3. Synthesis of $4(1 H)$-quinolone derivatives of Pseudocardia

3.4. Synthesis of intervenolin of Nocardia

3.5. Synthesis of $4(1 H)$-quinolones of the aurachin family

4. Conclusion

\section{Introduction}

Secondary metabolites have many important roles for microbial intra- and interspecies interactions. They serve for example as antibiotics against competing species, as virulence factors modulating host responses, or as signals to sense other cells of their own kin and trigger specific reactions in dependence of population density. Natural product isolation and structure elucidation have continuously increased the chemical space of microbial metabolites and shed light on the amazing biochemical capabilities of microbes. However, investigating their biological activity is often limited by the availability of sufficient quantities of pure compound. For this reason, bioassays typically focus only on a small set of antimicrobial and anticancer activities and a full functional characterization of many if not most microbial secondary remains elusive. $A$ robust and scalable strategy for the synthesis of the corresponding compounds provides thus an important prerequisite to gain a more comprehensive understanding of the range of biological activities of a natural product. Some Pseudomonas and Burkholderia species feature biosynthetic gene clusters to produce derivatives of 2-alkyl-4(1H)-quinolones. These quinolones are produced in particular by Pseudomonas aeruginosa and members of the Burkholderia cepacia complex which are important pathogens for cystic fibrosis patients. Although the number of producing species is small, the diversity of quinolones produced by them is remarkable: $P$. aeruginosa produces more than 50 different quinolone derivatives. ${ }^{1}$ This is achieved by a diversity-oriented biosynthetic machinery that allows the synthesis of different classes of quinolones and operates on a certain level of promiscuity to generate congeners with different chain lengths and saturation.

Other genera and species also produce similar quinolone derivatives such as Pseudocardia and Nocardia species and several myxobacteria and actinobacteria. ${ }^{2-5}$

These compounds have many interesting biological activities which are in part reviewed elsewhere. ${ }^{6}$ Some of them function as quorum sensing signals that allow their producers to coordinate virulence and other behaviours in dependence of population density. Others are mainly considered to act as anti-bacterial weapons deployed against competing species. Furthermore, some of these quinolones even mediate interkingdom interactions and impair the human immune response. 
Investigating the diversity of the biological activities and functional specialization of different congeners requires robust strategies for the synthesis of these 2-alkyl-4(1H)-quinolone derivatives. Finally, these strategies will potentially allow to synthetically exploit these molecules for human use. Here we will review the approaches and developments described so far in the synthesis of bacterial 2-alkyl-4(1H)quinolones to the best of our knowledge.

\section{Natural Diversity of 2-Alkyl-4(1H)-quinolones}

The ability of Pseudomonas aeruginosa to produce quinolones had been already discovered in the 1950 s. These quinolone derivatives were identified from culture supernatants as antagonists of dihydrostreptomycin, cytochrome inhibitors and antibacterial compounds. ${ }^{7-10}$ Since then, a great diversity of bacterially produced quinolones has been characterized serving distinct and highly specialized biological purposes. In Pseudomonas aeruginosa these metabolites are produced by a series of enzymes encoded by the pqs gene cluster starting from anthranilic acid. The divergent biosynthetic pathway generates three classes of $4(1 H)$-quinolones: congeners of the Pseudomonas quinolone signal (PQS, 1), 2-alkyl-4(1H)-quinolone (AQs or pseudanes, 2), and 2-alkyl-4(1H)-quinolone $N$-oxides (AQNOs, 3). Since the enzyme complex PqsBC, which is responsible for quinolone biosynthesis, exhibits substrate promiscuity for diverse CoA-activated fatty acids, all classes are produced as mixtures of congeners with saturated and unsaturated $C_{5}-C_{11}$ alkyl chains. ${ }^{11}$

Most research has focussed on the corresponding congeners with a saturated heptyl-chain, which are PQS, 2-heptyl-4(1H)-quinolone (HHQ), and 2-heptyl-4(1H)-quinolone $N$-oxide (HQNO) (Figure 1 ). ${ }^{12-14} \mathrm{PQS}$ and its biosynthetic precursor $\mathrm{HHQ}$ are quorum sensing signals that are produced in dependence of population density and detected by the signal receptor PqsR (MvfR). Signal binding positively regulates transcription of the pqs $A B C D E$ operon and controls together with the $r h l$ and las homoserine lactone quorum sensing systems the activation of virulence related genes in $P$. aeruginosa. ${ }^{15-16}$ In addition, $\mathrm{PQS}$ and $\mathrm{HHQ}$ have potential roles in competition with other microorganisms as well as repressing the human immune response. ${ }^{17-20}$

In contrast, AQNOs like HQNO do not participate in quorum sensing and have roles as weapons against competing species. ${ }^{21}$ In many Burkholderia species, a methyltransferase (HmqG) encoded in the biosynthetic gene cluster additionally results in the production of 3-methyl-AQs (MAQs, 4) or 2-methyl-AQNOs (MAQNOs, 5) (Figure 1). ${ }^{22}$ Some of these quinolones also feature double bonds with a different pattern such as $A Q s$ and AQNOs that mainly exhibit $\Delta^{1}$ unsaturated alkyl chains and MAQs and MAQNOs that predominantly feature $\Delta^{2}$ unsaturation.

Importantly, congeners of AQs, MAQs, AQNOs, and MAQNOs show functional differentiation with major differences in their biological activities. The antibiotic activity of quinolone $N$-oxides against the human pathogen Staphylococcus aureus, for example, depended on an unsaturated alkyl chain and in particular on the position of the double bond as well as quinolone core methylation determined the antibiotic potency. ${ }^{23-24}$ Another class are the 2-geranylated $4(1 H)$-quinolones of Pseudocardia and Nocardia species, which include highly potent antibiotics against the intestinal pathogen Helicobacter pylori such as intervenolin (6, Figure 1). ${ }^{2-}$ ${ }^{3}$ Myxobacteria like Stigmatella and actinobacteria like Rhodococcus and Streptomyces produce aurachins, a structurally diverse class of compounds that among others also comprises 4(1H)-quinolones 10 (C-type aurachins) and their $\mathrm{N}$-oxides. These aurachins are farnesylated in 3-position and feature a methyl-group in 2position and exhibit antibiotic activities mainly against gram-positive bacteria (Figure 1). ${ }^{5}$ 


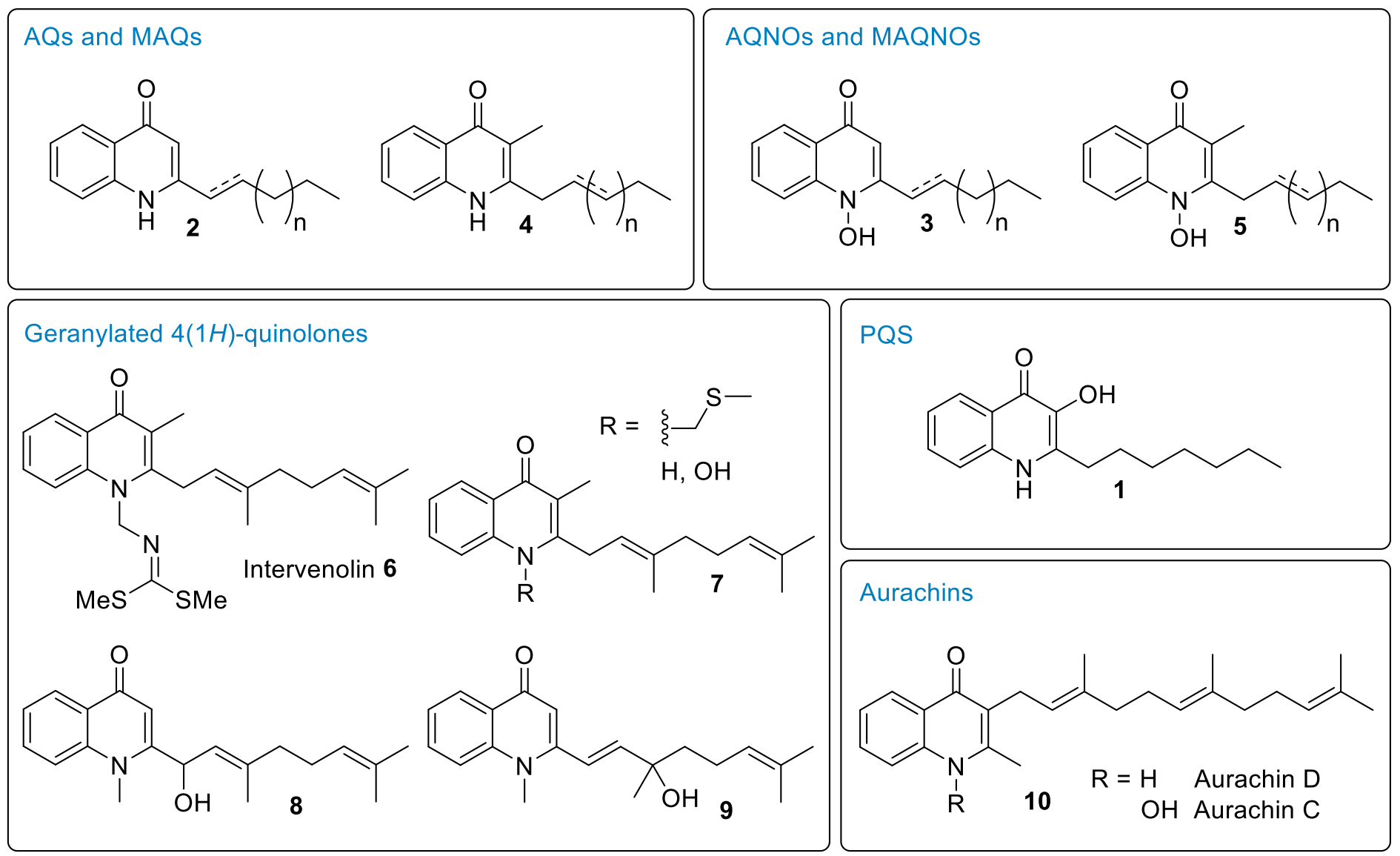

Figure 1. Overview of representative members of the different classes of microbially produced 2 -alkyl-4(1H)quinolones.

All bacterial 2-alkyl-4(1H)-quinolone derivatives also can be represented in their tautomeric form as corresponding 4-hydroxyquinolines (Figure 2). Under conditions of their synthesis or purification, we only observed the 2-alkyl-4(1H)-quinolone forms. However, the tautomeric equilibrium in aqueous media under microbial growth conditions has not been investigated so far. Several naming conventions of bacterial quinolones are therefore related to the tautomeric 4-hydroxyquinoline forms. For example, $\mathrm{HHQ}$ is the initial abbreviation for 2-heptyl-4-hydroxyquinoline. Also, the class of quinolone $N$-oxides is historically termed as such although the compounds are typically found in their 2-heptyl-1-hydroxy-4(1H)-quinolone form. 3Methylated 2-alkyl-4(1H)-quinolones (MAQs) are thus frequently termed HMAQs for 4-hydroxy-3-methyl-2alkenylquinolines and HMAQNOs for their corresponding $N$-oxides.

While this article explicitly focuses on synthetic strategies of microbial 2-alkyl-4(1H)-quinolones, several excellent reviews provide more detailed overviews about naturally produced 2-alkyl-4(1H)-quinolone derivatives and their biological activities. ${ }^{6,21,25-26}$ 
<smiles>[R]c1[nH]c2ccccc2c(=O)c1[R]</smiles><smiles>C=C=C</smiles><smiles>[R]c1nc2ccccc2c(O)c1[R]</smiles>

PQS-type<smiles>[R]c1[nH]c2ccccc2c(=O)c1O</smiles>

$$
1
$$<smiles>[R]c1nc2ccccc2c(O)c1O</smiles>

AQNO/MAQNO-type<smiles>[R]c1c([R])n(O)c2ccccc2c1=O</smiles><smiles>C=C=C</smiles><smiles>[R]c1c(O)c2ccccc2[n+]([O-])c1[R]</smiles>

AQ/MAQ-type

$$
\begin{array}{lll}
\mathbf{R}^{2} & \multicolumn{1}{c}{\mathbf{R}^{1}} & \\
\mathrm{H} & n \text {-heptyl } & \mathrm{HQ} \text { (HHQ) } \\
\mathrm{CH}_{3} & n \text {-heptyl } & \mathrm{MHQ}(\mathrm{HMHQ}) \\
\mathrm{H} & n \text {-nonyl } & \mathrm{NQ} \\
\mathrm{CH}_{3} & n \text {-nonyl } & \text { MNQ (HMNQ) }
\end{array}
$$

PQS-type

$$
\begin{array}{cc}
\mathbf{R}^{1} & \\
n \text {-heptyl } & \mathrm{C}_{7} \text {-PQS } \\
n \text {-nonyl } & \mathrm{C}_{9} \text {-PQS }
\end{array}
$$

AQNO/MAQNO-type

$\mathbf{R}^{\mathbf{2}} \quad \mathbf{R}^{\mathbf{1}}$

H n-heptyl HQNO

$\mathrm{CH}_{3} \quad n$-heptyl MHQNO

$\mathrm{H} n$-nonyl NQNO

$\mathrm{CH}_{3} \quad n$-nonyl MHQNO

Figure 2. Tautomers of natural 2-alkyl-4(1H)-quinolone derivatives.

\section{Synthetic Strategies}

\subsection{Synthesis of quinolone derivatives of Pseudomonas aeruginosa}

Pseudomonas aeruginosa is known to produce 2-alkyl-4(1H)-quinolones (AQs), 2-alkyl-3-hydroxy-4(1H)quinolones (PQS-type), and 2-alkyl-4(1H)-quinolone $N$-oxides (AQNOs) as a series of congeners with different alkyl-chain lengths that typically range from $C_{5}$ to $C_{13}$ and peak at odd-numbered $C_{7}$ and $C_{9}$ congeners. ${ }^{1,24}$

Best investigated and most commonly represented are congeners with a heptyl-chain like 2-heptyl4(1H)-quinolone (HHQ), 2-heptyl-3-hydroxy-4(1H)-quinolones (PQS), and 2-heptyl-4(1H)-quinolone $N$-oxide (HQNO). However, different congeners exhibit remarkable differences in their biological activity. For example, unsaturated AQNO congeners displayed greatly enhanced antibiotic activity against Staphylococcus aureus while saturated congeners were substantially less active. ${ }^{23}$ Recently, additional congeners with unusual branched side chains, methylthiovinyl, and benzyl substitutions have been reported. ${ }^{27}$ Robust synthetic strategies for the synthesis of these quinolones are thus important for providing access to the diverse naturally occurring quinolone classes and their congeners in order to elucidate their biological roles.

3.1.1. Synthesis of 2 -alkyl-4(1H)-quinolone congeners. The first synthesis of 2 -heptyl-4(1H)-quinolone (2a), 2nonyl-4(1H)-quinolone (2b) and a 2-( $\Delta^{1}$-nonenyl)-4(1H)-quinolone (2c) was reported by Wells 1952 and provided the proof that the metabolites (previously named Pyo $\mathrm{lb} / \mathrm{c}$ and Pyo III) isolated from Pseudomonas aeruginosa were indeed different congeners of 2 -alkyl-4(1H)-quinolones. ${ }^{28}$ This Conrad-Limpach reaction from $\beta$-ketoesters 11 and aniline is still the most commonly used method for the synthesis of 2 -alkyl-4(1H)quinolones (Scheme 1). ${ }^{23-24,29-30}$ 


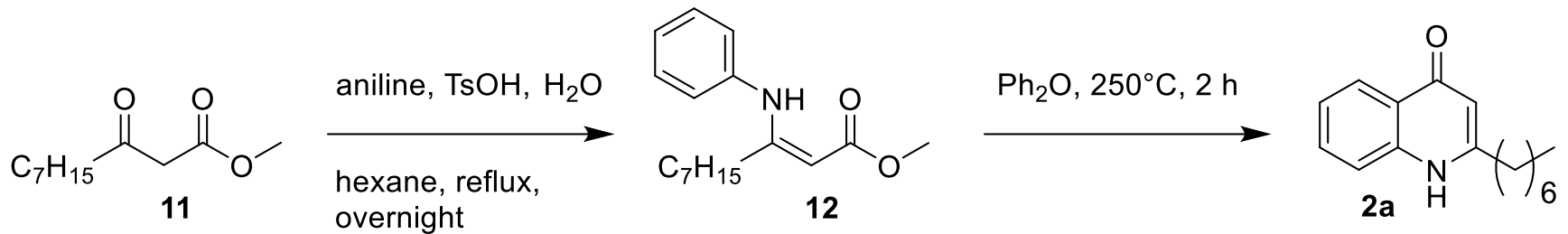

Scheme 1. Synthesis of 2-heptyl-4(1H)-quinolone (HHQ) by Conrad-Limpach reaction.

The corresponding $\beta$-keto esters can be obtained by the reaction of acid chlorides with Meldrum's acid in pyridine and subsequent alcoholysis under reflux conditions. Acid-catalyzed condensation of $\beta$-keto esters 11 with aniline affords the enamine tautomer of the Schiff base $\mathbf{1 2}$ that upon heating undergoes Conrad-Limpach cyclization. Finally, the 2-alkyl-4(1H)-quinolones $\mathbf{2}$ can be obtained in good yield and excellent purity by precipitation with non-polar solvents such as ether or $n$-hexane. The short reaction sequence and easy accessibility of the starting materials, $\beta$-keto esters and aniline, have certainly contributed to the success of this method.

Another strategy for the synthesis of 2-alkyl-4(1H)-quinolones 2 was published by Beifuss and Ledderhose. ${ }^{31}$ Here, they used $\mathrm{N}$-Cbz protected quinolones $\mathbf{1 3}$ which were locked as 4-silyloxyquinolinium triflates 14 to direct the regioselective addition of alkyl-Grignard reagents on the 2-position. Subsequent deprotection of the Cbz-group with $\mathrm{Pd} / \mathrm{C}$ and $\mathrm{H}_{2}$ yielded the corresponding 2-alkyl-4(1H)-quinolones 2 by an unexpected Saegusa-Ito-type oxidation reaction (Scheme 2).<smiles>Cn1ccc(=O)c2ccccc21</smiles>

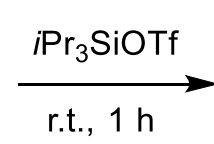

$13 \mathrm{Cbz}$

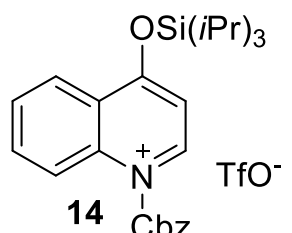

$14 \stackrel{\mathrm{C}}{\mathrm{Cbz}}$

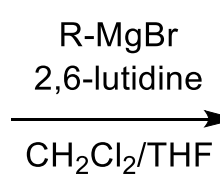<smiles>[R]C1C=C(O[AlH2])c2ccccc2N1[13CH3]</smiles>

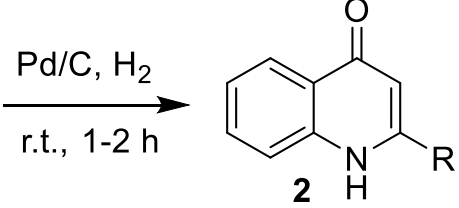

$\mathrm{R}=n$-pentyl (2d)

Scheme 2. Synthesis of 2-alkyl-4(1H)-quinolones by regioselective Grignard addition.

More recently, Wu et al. developed a gold-catalyzed cyclization reaction of 1-(2'-azidoaryl) propynols 16 to HHQ $2 \mathrm{a}$ and 2,3-disubstituted $4(1 \mathrm{H})$-quinolones including 2-aryl substituted compounds produced by the plant family Rutaceae. (Scheme 3 ). ${ }^{32}$

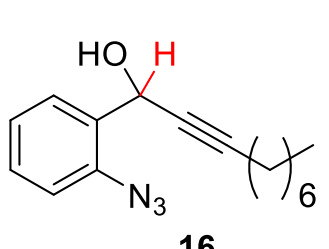

16

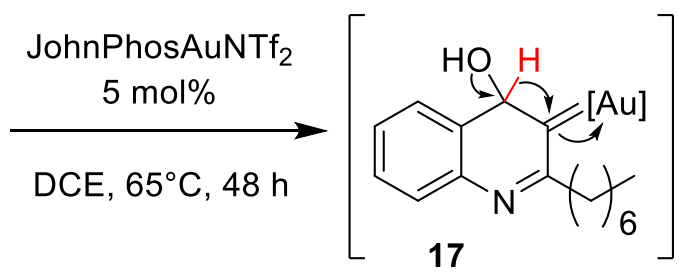

17

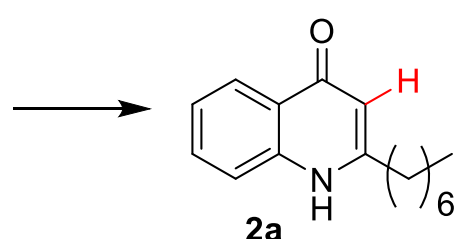

$2 a$

Scheme 3. Gold-catalyzed synthesis of HHQ via an $\alpha$-iminogold carbene intermediate. ${ }^{32}$

Singh et al. developed a one-pot reaction for the synthesis of 2-substituted $4(1 H)$-quinolones. This reaction started from ortho-bromoaryl ynones 18, following tandem Michael addition of ammonia and $\mathrm{Cu}(\mathrm{I})$ mediated aryl amidation reaction. The ammonia was in situ generated from ammonium carbonate which also 
served as a base. This reaction allowed to synthesize various pseudanes (AQs) but also plant produced quinolones like waltherione F, graveoline and graveolinine (Scheme 4). ${ }^{33}$<smiles>[R]C#CC(=O)c1ccccc1Br</smiles><smiles>[R]c1cc(=O)c2ccccc2[nH]1</smiles>

\section{Selected example}<smiles>[R]c1cc(=O)c2ccccc2[nH]1</smiles>

$\mathrm{R}=n$-butyl (pseudane IV) $(\mathbf{2 e})$ $n$-heptyl (pseudane VII or HHQ) (2a) $n$-octyl (pseudane VIII) (2f) n-dodecyl (pseudane XII) (2g)

Plausible mechanism<smiles>[R]C#CC(=O)c1ccccc1Br</smiles>

18<smiles>[R]C1=CC(c2ccccc2Br)=[O+]NC1</smiles>

19<smiles>[R]/C(N)=C/C(=O)c1ccccc1Br</smiles>

Cul<smiles>[R]c1cc(=O)c2ccccc2[nH]1</smiles>

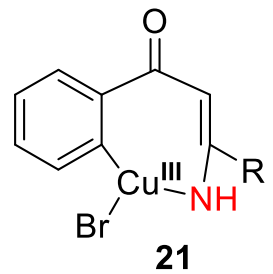
oxidative addition<smiles>[R]C(=CC(=O)c1ccccc1Br)NCl</smiles>

Scheme 4. One-pot synthesis of $\mathrm{HHQ}$ and $\mathrm{AQs}$ via Michael addition and $\mathrm{Cu}(\mathrm{I})$-mediated aryl amidation.

3.1.2. Synthesis of unsaturated and unusual 2-alkyl-4(1H)-quinolone congeners. Lohrer and Bracher developed a three-step route towards 2-alkenyl-4(1H)-quinolones starting from 2-methyl-4(1H)-quinolones comprising a Horner-Wadsworth-Emmons olefination as the key step. To preclude $\mathrm{N}-\mathrm{H}$ deprotonation, the 2methyl-4(1H)-quinolone 22 was converted to a 2-(trimethylsilyl)ethoxymethyl-protected 4-hydroxyquinoline 23. A one-pot phosphorylation-alkenylation reaction coupling phosphonium salts with aldehydes yielded $\Delta^{1}$ unsaturated $O$-protected 2-alkyl-4(1H)-hydroxyquinolines 24 . Deprotection ultimately gave the corresponding 2-alkenyl-4(1H)-quinolones 2 in (E)-configuration (Scheme 5). ${ }^{34}$

Further strategies towards the synthesis of unsaturated AQs are reported in section 3.1.4. along with the synthesis of the corresponding AQNOs. 


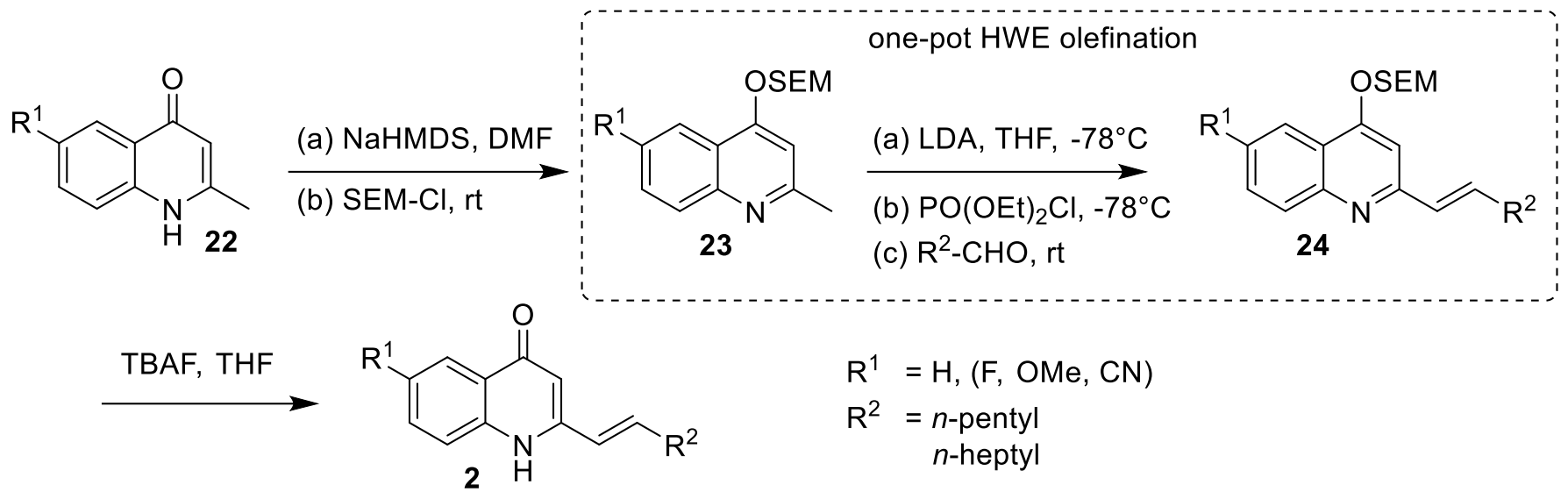

Scheme 5. Synthesis of 2-alkenyl-4(1H)-quinolones using the Horner-Wadsworth-Emmons olefination reaction.<smiles>CC(=O)c1ccccc1N</smiles>

25<smiles>C#CC(=O)Nc1ccccc1C(=O)OCCOCCOCCO</smiles><smiles>CNc1ccccc1C(C)=O</smiles><smiles>[Y9]C(=[Pt])/C=C\SC</smiles><smiles>CS/C=C/c1cc(=O)c2ccccc2[nH]1</smiles><smiles>COC(=O)C#CC(=O)OC</smiles>

28 (a) $\mathrm{MeOH}$
reflux

(b) PPA $130^{\circ} \mathrm{C}$

$130^{\circ} \mathrm{C}$<smiles>CC(=O)c1cc(=O)c2ccccc2[nH]1</smiles><smiles>[R]B(O)OC1(C)OB([R17])OC1(C)C1(C)OB(O)OC1(C)O</smiles><smiles>[R]Cc1cc(=O)c2ccccc2[nH]1</smiles>

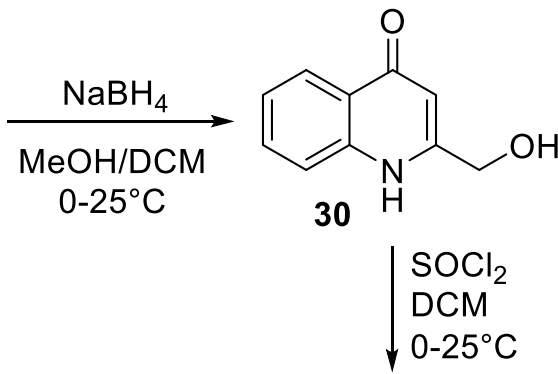

\section{Selected examples}<smiles>[R]c1cc(=O)c2ccccc2[nH]1</smiles>

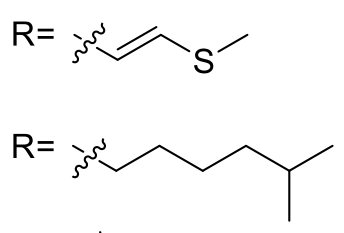<smiles>[R][Te]Cc1ccccc1</smiles><smiles>[R][C][14CH]C(O)CCCCCCC</smiles><smiles>[R][C]C=C(C)CC</smiles>

$\mathrm{R}=$<smiles>CCCCC=CCCCCC</smiles>

Scheme 6. Synthesis of $4(1 H)$-quinolone produced by a Chinese isolate of $P$. aeruginosa BD06-03. 
Recent work of the Clark group led to the discovery of several new quinolones with unusual side chains in 2-position which could be isolated from the Chinese $P$. aeruginosa strain BD06-03. ${ }^{27}$ These included unprecedented $4(1 H)$-quinolones with unsaturated branched side chain, methylthiovinyl $2 \mathrm{~h}$, and benzyl substitutions 2k. Ultimately, total synthesis reported by the same group gave access to some of these compounds for biological testing and revealed interesting activities against the growth of Staphylococcus aureus, Bacillus subtilis and even another strain of $P$. aeruginosa. ${ }^{27,} 35$ Two different synthetic routes were applied to the synthesis of the arylated and unsaturated quinolones and methylthiovinyl-substituted quinolones (Scheme 6). The methylthiovinyl side chain $\mathbf{2 h}$ was synthesized starting from a ketoaryl propiolamide $\mathbf{2 5}$ derivative before base-promoted Camps cyclization. Michael addition of methanthiolate on the alkynyl group of the propiolamide $\mathbf{2 6}$ yielded the methylthiovinyl substituted ketoaryl amide $\mathbf{2 7}$. Finally, the $4(1 H)$-quinolone $\mathbf{2} \mathbf{k}$ was obtained by base-promoted cyclization. In contrast, the benzyl and unsaturated side chain substituted $4(1 H)$-quinolones were obtained via coupling of the quinolone core $\mathbf{3 1}$, established by the Conrad-Limpach reaction, with the corresponding boronic esters via the Suzuki-Miyaura cross-coupling reaction. ${ }^{35}$

3.1.3. Synthesis of the Pseudomonas Quinolone Signal (PQS). PQS 1 was discovered as a cell-to-cell signalling molecule that regulates virulence factor production and designated the term Pseudomonas quinolone signal (PQS). The first synthesis of PQS was described in 1999 along with its discovery by Pesci et al. ${ }^{36}$ The reaction starts from HHQ 2a with the formylation of its 3-position by a Duff-reaction. Here, hexamine (urotropine) is applied as the formyl carbon source. Subsequent oxidation of the 3-formyl-2-heptylquinolone 32 via Dakin reaction with hydrogen peroxide afforded PQS 1 in 74\% yield (Scheme 7). This method has been frequently used for synthesis PQS since then. ${ }^{29}$ A similar strategy was already reported in 1962 by Morgan et al. where Dakin oxidation of 3-formyl-4-hydroxyquinolines was applied in the synthesis of 2-phenyl and 2-methyl-3hydroxy-4(1H)-quinolones. ${ }^{37}$

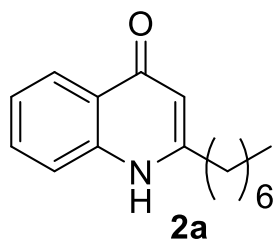

(a) hexamine, TFA, reflux, $27 \mathrm{~h}$

(b) $\mathrm{MeOH} / \mathrm{H}_{2} \mathrm{O} 1: 1$, $\mathrm{HCl}$, reflux, $0.8 \mathrm{~h}$
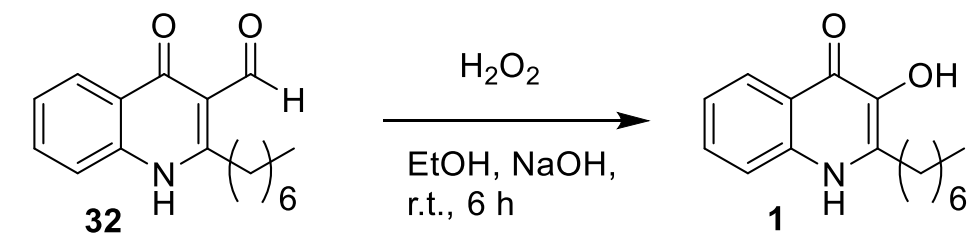

Scheme 7. The first synthesis of PQS reported. ${ }^{36}$

While this synthetic approach has the advantage to build on 2-alkyl-4(1H)-quinolones like HHQ 2a, analogous to the biosynthesis of PQS 1 , the Duff reaction and Dakin oxidation were reported to be somewhat unreliable. ${ }^{38-39}$ Formylation was only successful when HHQ 2 a was previously converted into its 4hydroxyquinoline tautomer. ${ }^{39}$

A strategy to directly convert $4(1 H)$-quinolones to 3-hydroxy-4(1H)-quinolones was reported by Behrman et al. using an Elbs peroxodisulfate oxidation and acid-catalysed hydrolysis of the resulting sulfates. ${ }^{40}$ However, the method has not yet been applied for the synthesis of natural 2-alkyl-3-hydroxy-4(1H)quinolones.

A facile and more direct strategy towards 3-hydroxylated quinolones 1 was described in 1999 by Hradil et al. ${ }^{41}$ To this end, anthranilic acid (33) is esterified with $\alpha$-chloro- or $\alpha$-bromoketones giving the respective 2 oxoalkyl 2'-aminobenzoates $\mathbf{3 4}$ in good yields. Cyclization is achieved by heating the esters with 
polyphosphoric acid at $120^{\circ} \mathrm{C}$ or under reflux with $\mathrm{N}$-methylpyrrolidone (NMP) yielding the corresponding 2alkyl-3-hydroxy-4-quinolones 1 (scheme 8). ${ }^{41}$ This strategy was originally developed for non-natural 2-methyl and 2-phenyl 3-hydroxy-4(1H)-quinolones, but has since been adapted as a major route for the synthesis of PQS. ${ }^{39,} 42$<smiles>Nc1ccccc1C(=O)O</smiles>

33

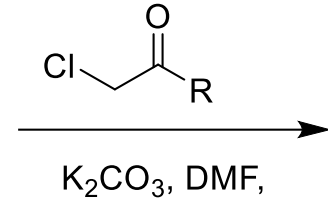

r.t. to $50^{\circ} \mathrm{C}, 1 \mathrm{~h}$<smiles>[R]C(=O)COC(=O)c1ccccc1N</smiles>

34

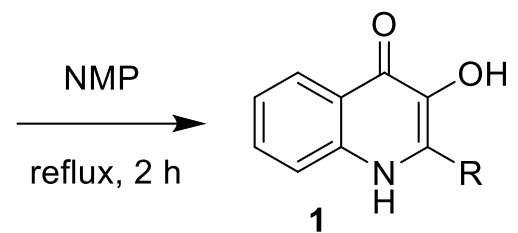

1

Scheme 8. Synthesis of 2-alkyl-3-hydroxy-4-quinolone according to Hradil et al. ${ }^{41}$

Although the exact mechanism of cyclization in this reaction is not fully understood, a similar reaction to 2-phenyl-3-amino-4(1H)-quinolones gave a seven-membered diazepinone which rearranged to 2-phenyl-3amino-4-quinolone upon heating in polyphosphoric acid. ${ }^{43}$ An analogous rearrangement can be proposed for the synthesis of 3-hydroxy-4(1H)-quinolones. ${ }^{38}$

A similar strategy was developed by the Spring lab in order to achieve a facile synthetic access to a wide range of PQS 1 derivatives using a one-pot microwave-assisted synthesis of $\alpha$-chloroketones $\mathbf{3 6}$ with anthranilic acid derivatives (Scheme 9). ${ }^{38,44}$ These conditions were further optimized for a continuous flow reaction that allowed the gram-scale synthesis of PQS and its derivatives. ${ }^{38}$ The resulting PQS analogues allowed to conduct a comprehensive investigation of structure-activity relationships for stimulating the quorum sensing receptor MvfR (PqsR). ${ }^{45}$

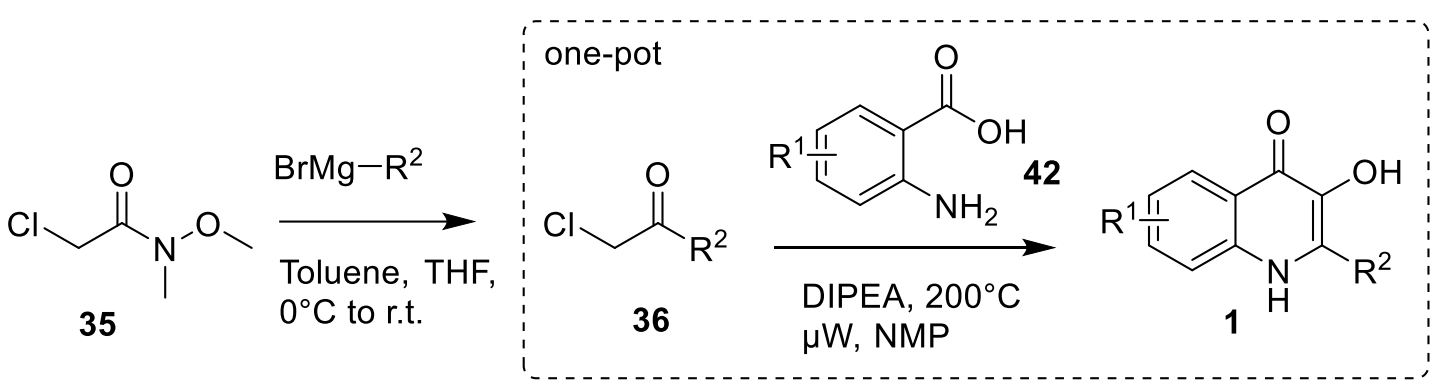

Scheme 9. Microwave-assisted and continuous flow synthesis of PQS analogues.

3.1.4. Synthesis of $\mathbf{2}$-alkyl-4(1H)-quinolone $\mathbf{N}$-oxides. 2 -Alkyl-4(1H)-quinolone $\mathbf{N}$-oxides $\mathbf{3}$ are important metabolites of $P$. aeruginosa with diverse anti-microbial and anti-protozoal activities. ${ }^{13,23,46-48}$

In 1956, Cornforth and James were the first to isolate AQNOs 3 from culture supernatants of $P$. aeruginosa and characterize their structures. ${ }^{8}$ They also reported the first synthesis of HQNO $3 a$ by $O$-ethoxycarbonyl protection of 2-heptyl-4( $1 \mathrm{H})$-quinolone and $\mathrm{N}$-oxidation using peroxybenzoic acid. For preparative purposes, they used a condensation of $\beta$-ketoesters 37 with o-nitrobenzoyl chloride followed by hydrolytic decarboxylation and reduction of the nitro-group 39 by $\mathrm{SnCl}_{2}$ upon which direct cyclization to the corresponding $\mathrm{N}$-oxides $\mathbf{3}$ was achieved. By applying this method, AQNOs with heptyl- (3a), nonyl- (3b), and undecyl (3c)-chains were synthesized (Scheme 10). ${ }^{8}$ 
<smiles>[R]C(=O)CC(=O)OC</smiles>

37 (a) $\mathrm{Na}(\mathrm{s})$,

(b) toluene<smiles>O=C(Cl)c1ccccc1[N+](=O)[O-]</smiles><smiles>[R]C(=O)C(C(=O)OC)C(=O)c1ccccc1[N+](=O)[O-]</smiles><smiles>[R]C(=O)CC(=O)c1ccccc1[N+](=O)[O-]</smiles>

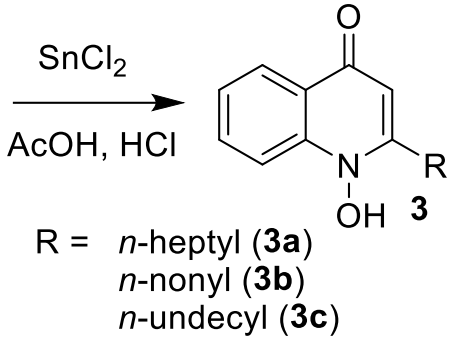

Scheme 10. Direct synthesis of AQNOs.

More frequently, however, AQNOs 3 have been generated from the corresponding AQs by subsequent protection, $\mathrm{N}$-oxidation by $m C P B A$ and deprotection (Scheme 11). ${ }^{49-50}$ To this end, different protection groups including O-ethoxycarbonyl (40) and benzyl (42) have been used. Deprotection of the oxidized 4hydroxyquinolines yields exclusively the $4(1 H)$-quinolone $N$-oxide 3 tautomeric form that can be clearly identified by the prominent ${ }^{13} \mathrm{C}-\mathrm{NMR}$ shift of the carbonyl-group which is only observable in $\mathrm{HMBC}$ spectra. ${ }^{23}$

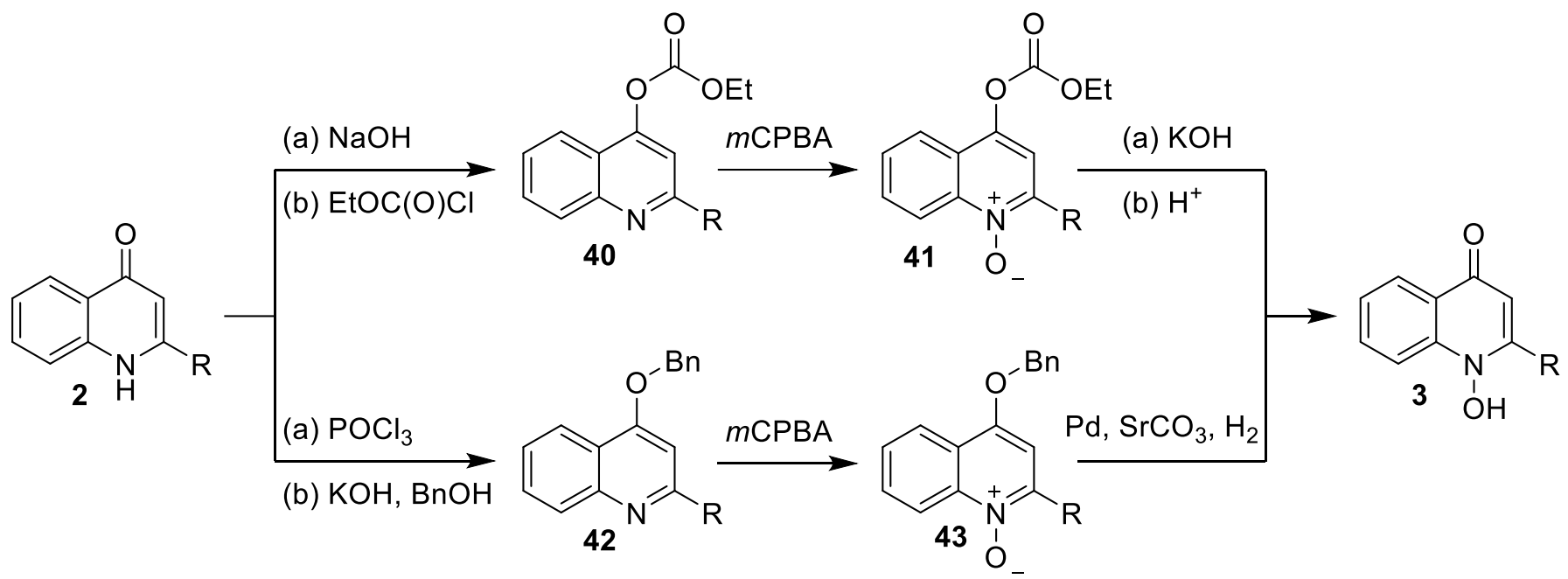

Scheme 11. Synthesis of $4(1 H)$-quinolone $N$-oxides.

Woschek et al. noticed a rearrangement of ethyl carbonate protected 2-alkyl-4(1H)-quinolone $\mathrm{N}$-oxides 41 to corresponding $N$-(ethoxycarbonyloxy)-4(1H)-quinolones 44 at room temperature over several days (Scheme 12). The $N$-(ethoxycarbonyloxy)-4(1H)-quinolones 44 crystallize readily and also can be deprotected by $\mathrm{KOH}$ to give the 2 -alkyl-4(1H)-quinolone $\mathrm{N}$-oxides. ${ }^{50}$<smiles>[Z1][R]c1cc(OC(=O)OCC)c2ccccc2[n+]1[O-]</smiles><smiles>[R]c1cc(=O)c2ccccc2n1OC(=O)OCC</smiles>

(a) $\mathrm{KOH}, \mathrm{EtOH}, \mathrm{H}_{2} \mathrm{O}$

(b) $\mathrm{H}^{+}, \mathrm{H}_{2} \mathrm{O}$<smiles>[R]c1cc(=O)c2ccccc2n1O</smiles>

Scheme 12. Rearrangement of ethyl carbonate protected 2-alkyl-4(1H)-quinolone $N$-oxides. 
Our laboratory has combined the strategy of Conrad-Limpach cyclization (Scheme 1) for the synthesis of the 2-alkyl-4(1H)-quinolone 1 core with $O$-ethoxycarbonyl protection, $N$-oxidation by $m C P B A$ and deprotection for the synthesis of chain-length congeners of AQNOs with saturated pentyl (PQNO, 2d), heptyl (HQNO, 2a), nonyl (NQNO, 2b) and undecyl (UQNO, 2i). ${ }^{23}$

The unsaturated trans- $\Delta^{1}$-NQNO 3d, one of the main AQNOs of $P$. aeruginosa, was synthesized via the corresponding trans- $\Delta^{1}-\mathrm{NQ} \mathbf{2 c}$ by Camps cyclization and subsequent ethyl carbonate protection, $N$-oxidation and deprotection (Scheme 13). ${ }^{23}$

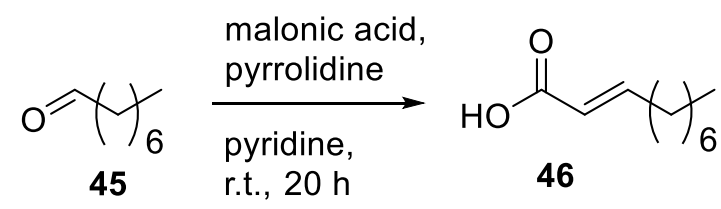

(a) oxalyl chloride, cat. DMF, DCM, r.t., $1 \mathrm{~h}$

(b) 2'-aminoacetophenone, TEA, THF, r.t., $2 \mathrm{~h}$
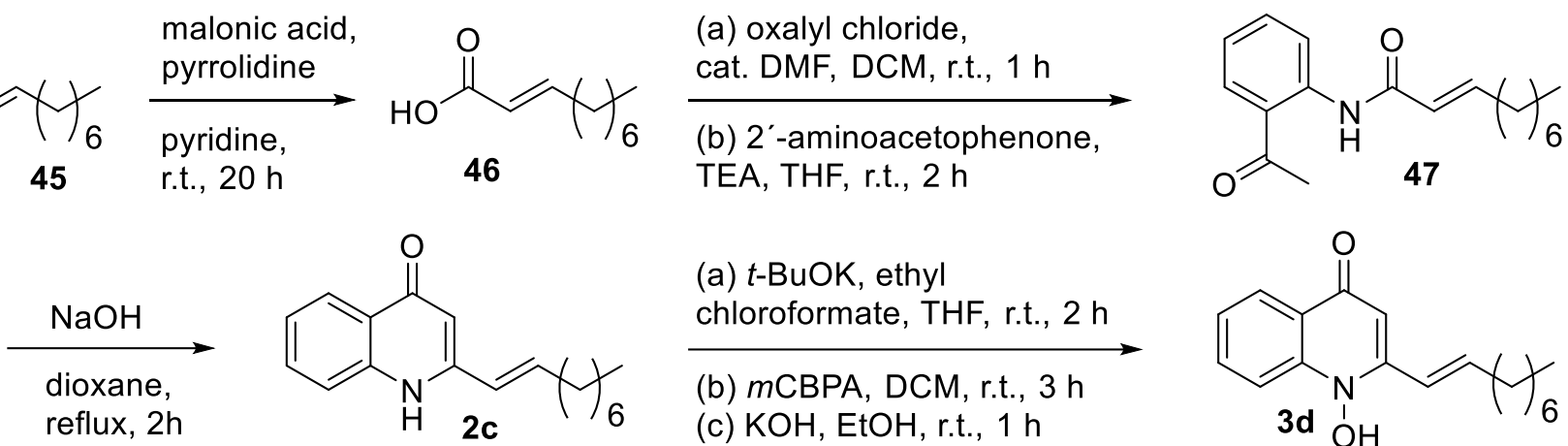

(a) $t$-BuOK, ethyl chloroformate, THF, r.t., $2 \mathrm{~h}$

(b) $m \mathrm{CBPA}$, DCM, r.t., $3 \mathrm{~h}$

(c) $\mathrm{KOH}, \mathrm{EtOH}$, r.t., $1 \mathrm{~h}$

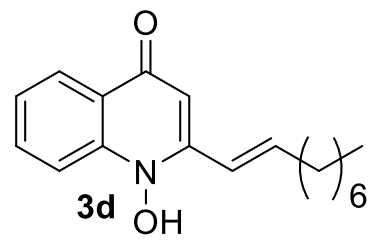

Scheme 13. Synthesis of the trans- $\Delta^{1}$-unsaturated NQNO of $P$. aeruginosa. ${ }^{23}$

3.2. Synthesis of MAQs and MAQNOs of Burkholderia. Species of the genus Burkholderia produce 2-alkyl-3methyl-4(1H)-quinolones (MAQs 4) and 2-alkyl-3-methyl-4(1H)-quinolone $N$-oxides (MAQNOs 5). 4(1H)Quinolones of the PQS-type have not been reported and the corresponding gene encoding for homologs of the monooxygenase PqsH is missing in Burkholderia. Recent work has shown that in addition to MAQs 4 and MAQNOs 5, Burkholderia thailandensis also produces lower amounts of the corresponding non-methylated AQs 2 and AQNOs $3 .^{24}$ While MAQs 4 are non-classical quorum sensing signals, ${ }^{51}$ the corresponding MAQNOs 5 are potent antimicrobial compounds, the activity of which strictly depends on the exact pattern of unsaturation, methylation and position of the double bond of the congener. ${ }^{24}$

2-Heptyl-3-methyl-4(1H)-quinolone (4a) was synthesized by Reen et al. by generating a methylated $\beta$ ketoester 11 with $\mathrm{Mel}$ and $\mathrm{K}_{2} \mathrm{CO}_{3}$ as base. Reaction with aniline to form the corresponding enamine followed by Conrad-Limpach cyclization of in diphenyl gave the final product (Scheme 14). ${ }^{29}$

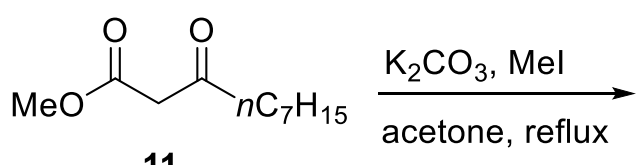

11

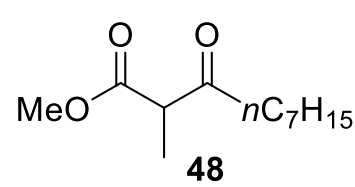

48

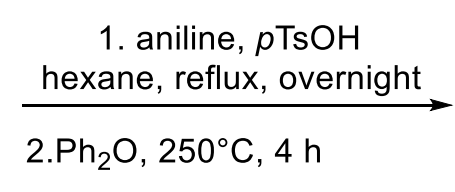

1. aniline, $p \mathrm{TsOH}$

2. $\mathrm{Ph}_{2} \mathrm{O}, 250^{\circ} \mathrm{C}, 4 \mathrm{~h}$

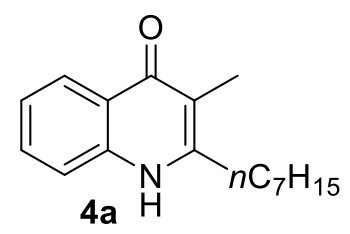

Scheme 14. Synthesis of 2-heptyl-3-methyl-4(1H)-quinolone using a Conrad-Limpach cyclization.

Our laboratory has reported the synthesis of saturated MNQNO 5a and a trans- $\Delta^{1}$-unsaturated 3methyl-2-nonyl-4(1H)-quinolone N-oxide (trans- $\Delta^{1}-M N Q N O 5 b$ ) by Camps cyclization of the corresponding 2'amidopropiophenones 49 (Scheme 15). ${ }^{24}$ The synthetic compounds were used as standards for mass spectrometric quantification of quinolone production by Burkholderia thailandensis and revealed that of the 
unsaturated quinolones only trans- $\Delta^{2}$-MNQNO 5c but not trans- $\Delta^{1}-M N Q N O 5 \mathbf{b}$ were present in culture supernatants.<smiles>[R]C(=O)Nc1ccccc1C(=O)CC</smiles>

(a) $t$-BuOK, ethyl chloroformate, THF, r.t., $2 \mathrm{~h}$

(b) $m \mathrm{CBPA}, \mathrm{DCM}$, r.t.

(c) $\mathrm{KOH}, \mathrm{EtOH}$, r.t.<smiles>[R]c1c(C)c(=O)c2ccccc2n1O</smiles>

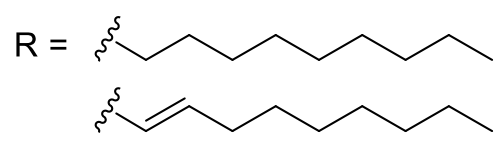

MNQNO (5a)

trans- $\Delta^{1}-\mathrm{MNQNO}$

Scheme 15. MAQ and MAQNO synthesis by Camps cyclization.

As one of the main quinolone $N$-oxides of Burkholderia thailandensis, trans- $\Delta^{2}-\mathrm{MNQNO} 5 \mathrm{c}$ was identified, which was synthesized by our laboratory along with trans- $\Delta^{2}$-NQNO $3 e$ via the corresponding NQ and MNQ 4d derivative. The synthesis was achieved by coupling of an octenyl pinacol boronic ester with 2(chloromethyl)quinolin-4(1H)-one 31 using a microwave assisted Suzuki-Miyaura reaction (Scheme 16). ${ }^{24}$ The same synthetic strategy was published in parallel in a collaboration of the Déziel and Gauthier laboratories for generating the three chain length congeners of trans- $\Delta^{2}-M A Q s$ and trans- $\Delta^{2}$-MAQNOs with heptenyl, octenyl, and nonenyl chains which demonstrated that trans- $\Delta^{2}-M N Q N O$ is the most active congener in antibiotic assays against various gram-negative and gram-positive bacteria. ${ }^{52}$
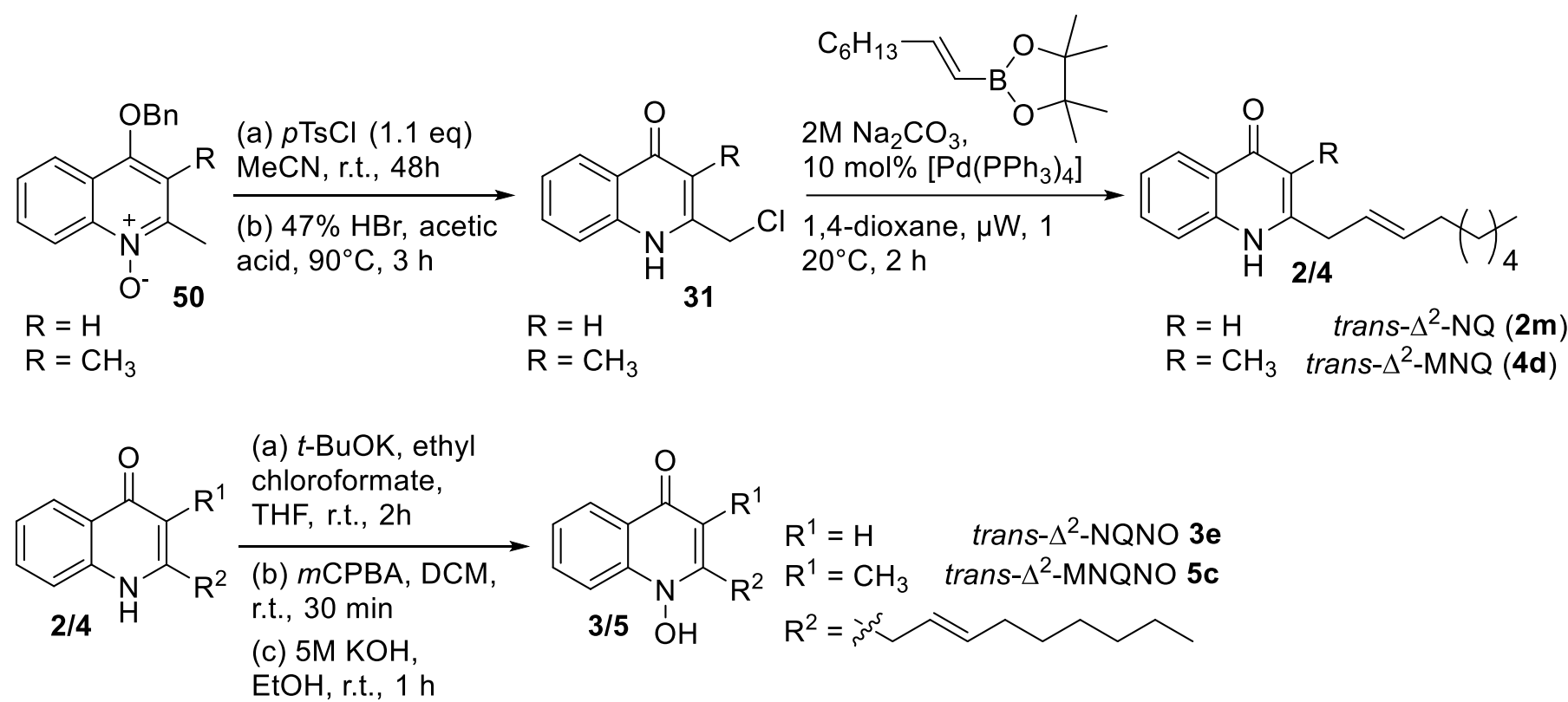

Scheme 16. Synthesis of trans- $\Delta^{2}$-unsaturated NQNO and MNQNO.

\subsection{Synthesis of $\mathbf{4}(\mathbf{1 H})$-quinolone derivatives of Pseudocardia}

The soil-isolate Pseudocardia sp. CL38489, an actinomycete, produces various 2-geranyl 4(1H)-quinolones with potent antibiotic activities against Helicobacter pylori. ${ }^{3}$ To synthesize these natural products, Salvaggio et al. 
reported a microwave-assisted Suzuki-Miyaura cross-coupling reaction between 2-(chloromethyl)quinolin$4(1 H)$-ones 31 and a pinacol boronic ester introducing the terpenoid side chain (Scheme 17). ${ }^{53}$

The corresponding 2-(chloromethyl)quinolin-4(1H)-ones 31 were obtained by Conrad-Limpach reaction of $\beta$-ketodiesters with aniline followed by reduction of the carboxylate in 2-position to the alcohol and chlorination with thionyl chloride. Since the dimethylated 2-(chloromethyl)-1,3-dimethylquinolin-4(1H)-one could be only produced in poor yields from $N$-methylaniline, a more suitable strategy by $N$-methylation of the tert-butyldimethylsilyl protected 2-(hydroxymethyl)-3-methylquinolin-4(1H)-one using iodomethane. ${ }^{53}$
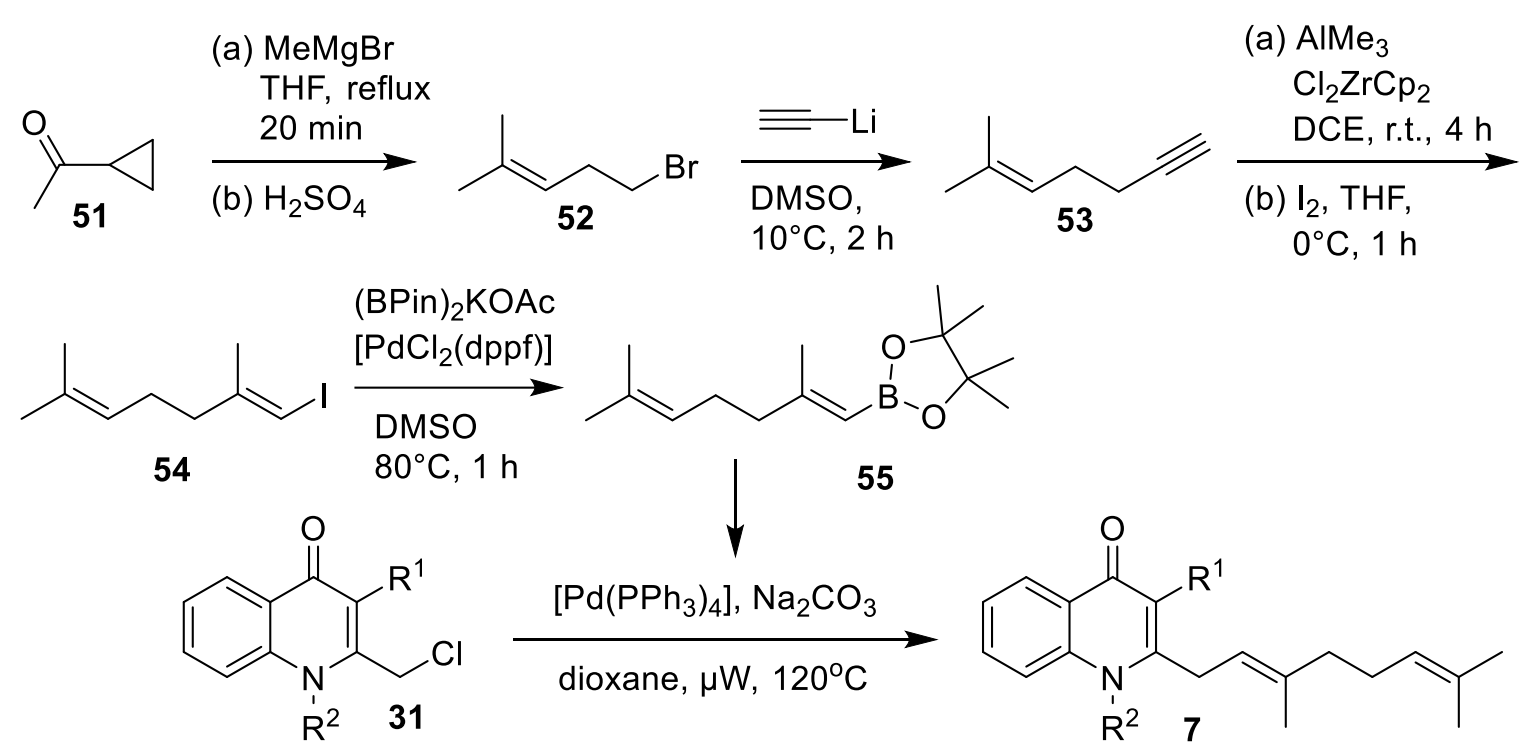

Selected examples Pseudonocardia sp. CL38489<smiles>CC(C)=CCC/C(C)=C/Cc1cc(=O)c2ccccc2[nH]1</smiles><smiles>CC(C)=CCC/C(C)=C/Cc1cc(=O)c2ccccc2n1C</smiles><smiles>CC(C)=CCC/C(C)=C/Cc1[nH]c2ccccc2c(=O)c1C</smiles><smiles>CC(C)=CCC/C(C)=C/Cc1c(C)c(=O)c2ccccc2n1C</smiles>

Scheme 17. Synthesis of metabolites of Pseudocardia sp. CL38489 using Suzuki-Miyaura cross coupling.

The synthesis of further substituted $4(1 H)$-quinolones of Pseudonocardia sp. CL38489 also was reported by the Spring laboratory. ${ }^{54}$ They used the same method of Suzuki-Miyaura cross-coupling between 2 (chloromethyl)quinolin-4(1H)-ones 31 and a pinacol boronic esters to generate 1- and 3-methylated 2-geranyl $4(1 H)$-quinolones. These were modified by epoxidation and methylthiomethylenation to the corresponding natural products of Pseudonocardia sp. CL38489 (Scheme 18). ${ }^{54}$ 

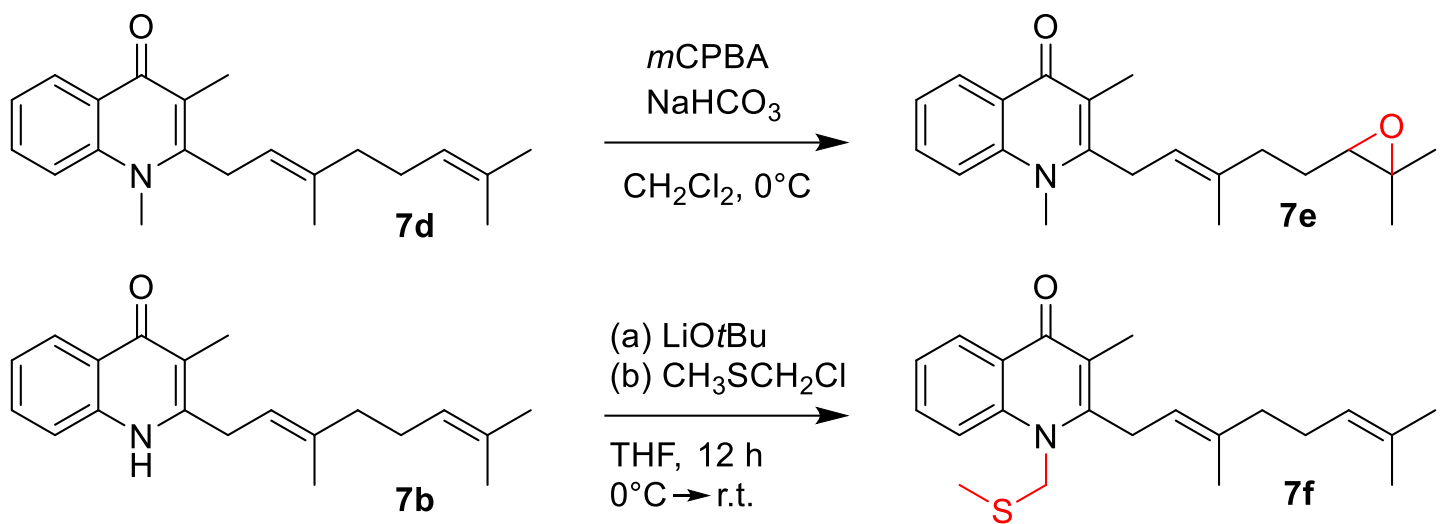

(a) $\mathrm{LiOtBu}$

(b) $\mathrm{CH}_{3} \mathrm{SCH}_{2} \mathrm{Cl}$

THF, $12 \mathrm{~h}$

$0^{\circ} \mathrm{C} \rightarrow$ r.t.<smiles>CSCn1c(CC=C(C)CCC=C(C)C)c(C)c(=O)c2ccccc21</smiles>

Scheme 18. Late stage diversification of 2-geranyl $4(1 H)$-quinolones.

In addition, two 4(1H)-quinolones metabolites with hydroxyl groups in the side chain (8 and 9) had been reported from Pseudocardia sp. CL38489. ${ }^{3}$ For the synthesis of these compounds, an alternative strategy to the Suzuki-Miyaura route had to be developed. Starting from geraniol (56), a MOM-protected propargylic alcohol 58 was generated which was subsequently used for Sonogashira coupling. Michael addition with methylamine and cyclization under Buchwald-Hartwig conditions gave the $N$-methyl $4(1 H)$-quinolone $\mathbf{6 1}$. Upon deprotection, a 1,3-allylic alcohol rearrangement gave rise to both hydroxylated natural products (Scheme 19)..$^{54}$ This strategy was also used to produce non-natural analogues of the $4(1 H)$-quinolones of Pseudocardia sp. CL38489, which exhibited activity in inhibition of pyocyanin production of $P$. aeruginosa. ${ }^{55}$

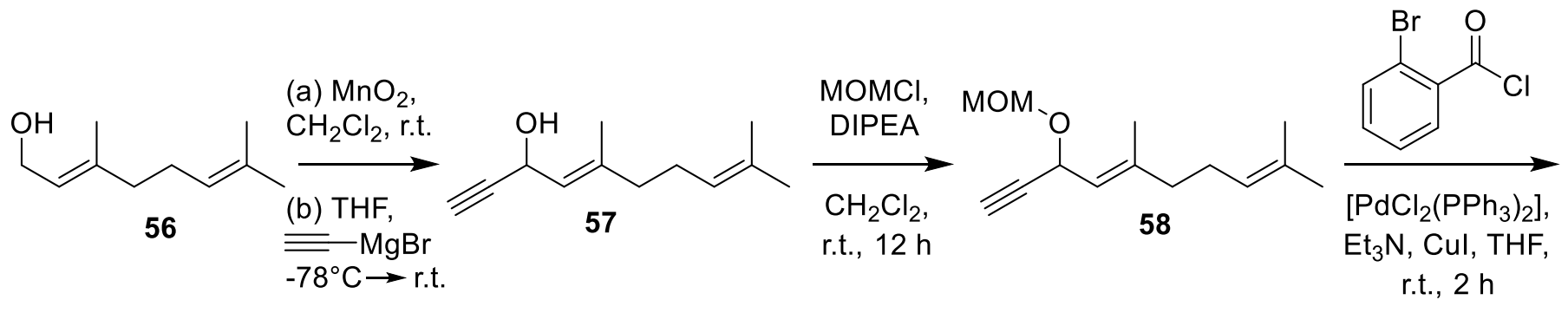<smiles>COC(C#CC(=O)c1ccccc1Br)C=C(C)CCC=C(C)C</smiles><smiles>COC(/C=C(\C)CC/C=C(/C)C(=O)OCc1ccccc1)c1cc(=O)c2ccccc2n1C</smiles><smiles>CC(C)=CCC/C(C)=C/C(O)c1cc(=O)c2ccccc2n1C</smiles><smiles>CC(C)=CCCC(C)(O)/C=C/c1cc(=O)c2ccccc2n1C</smiles>

Scheme 19. Synthesis of the hydroxylated 4(1H)-quinolones of Pseudocardia sp. CL38489 (PPTS = pyridinium p-toluenesulfonate). 


\subsection{Synthesis of intervenolin of Nocardia}

In 2013, Kawada et. al. discovered an $\mathrm{N}$-iminodithiocarbonate-4(1H)-quinolone, named intervenolin (6), as a metabolite produced by the gram-positive bacterium Nocardia sp. ML96-86F2. ${ }^{2}$ Intervenolin exhibited antitumor activities and potently and selectively inhibited the growth of the gastrointestinal pathogen Helicobacter pylori. ${ }^{2}$ Subsequently, total synthesis of intervenolin was developed combining Suzuki-Miyaura coupling with thiocyanate-isothiocyanate rearrangement as the key steps. ${ }^{56}$ The $4(1 \mathrm{H})$-quinolone core scaffold 62 was generated by Friedel-Crafts reaction via an anhydride produced by the reaction of the carboxylic acid 61 with Eaton's reagent $\left(\mathrm{P}_{4} \mathrm{O}_{10}\right.$ dissolved in methanesulfonic acid), followed by TBS protection of the hydroxygroup. The quinolone was locked in its tautomeric quinolinediol form and activated as triflate 63 for subsequent Suzuki-Miyaura reaction (Scheme 20). The geranyl side chain at 2-position was introduced via the corresponding boronic ester 64. Thiocyanomethylation of the $\mathrm{N}-1$ position followed by spontaneous rearrangement resulted in an isothiocyanate moiety 66. Finally, the isothiocyanate was captured by methyl thiolate and methylated by Mel to afford intervenolin (6). ${ }^{56}$
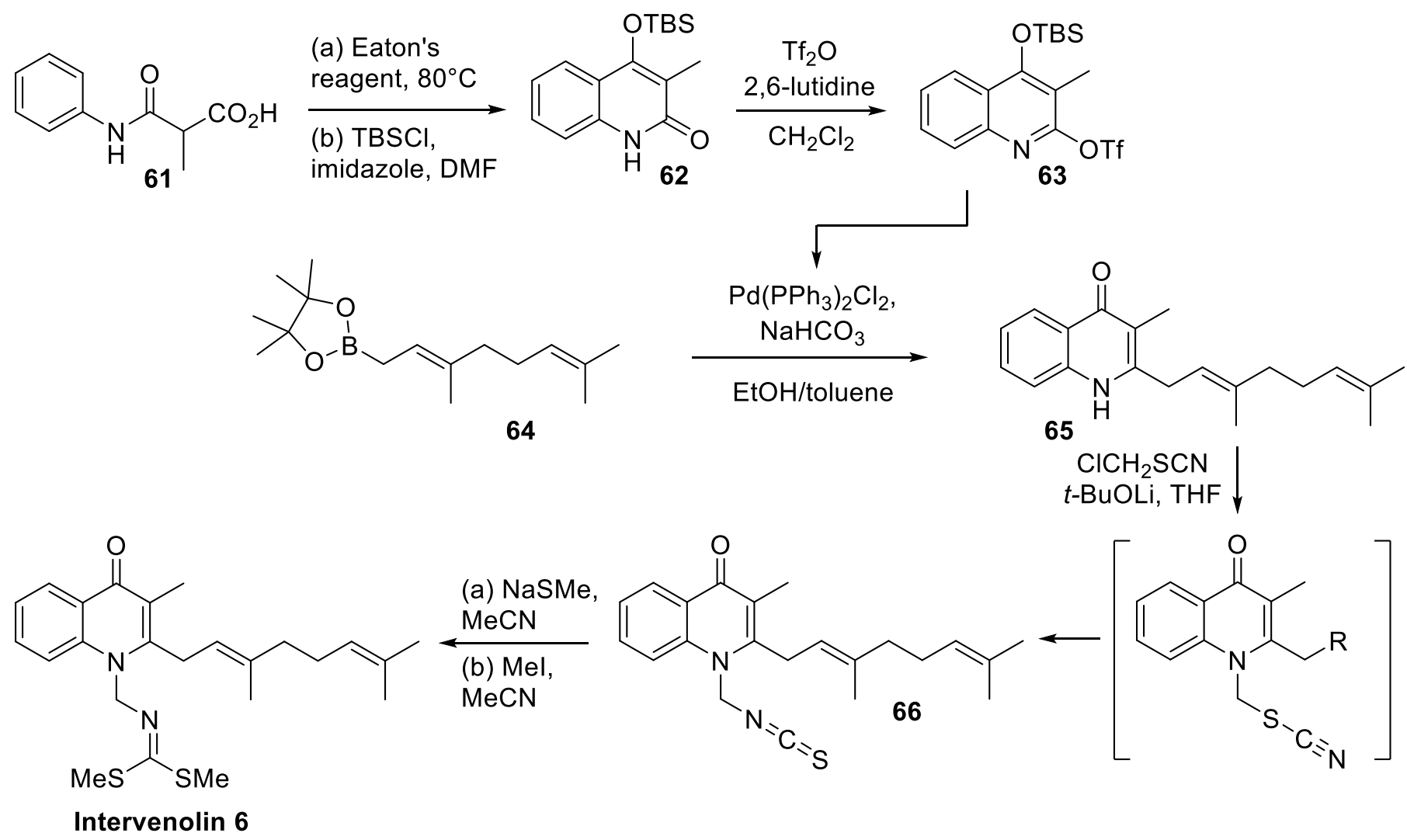

Scheme 20. Synthesis of intervenolin through Suzuki-Miyaura coupling. ${ }^{56}$

\subsection{Synthesis of $4(1 \mathrm{H})$-quinolones of the aurachin family}

Another class of $4(1 H)$-quinolones are C-type aurachins 10, which are methylated in 2-position, feature a farnesyl substitution on 3-position, and have been isolated from myxobacteria of the genus Stigmatella and actinobacteria like Rhodococcus and Streptomyces species. ${ }^{4-5,57}$ In 2013, Li et. al. reported the first synthesis of aurachin D (10a) through a three-step sequence starting from ethyl acetoacetate (67) which was farnesylated, condensed with aniline and cyclized to the $4(1 \mathrm{H})$-quinolone via the Conrad-Limpach reaction. ${ }^{58}$ Enomoto et. al. reported a 2-step synthesis of aurachins $C$ and D starting from farnesylation of 1-(2-nitrophenyl)butane-1,3- 
dione 69 , following by reductive cyclization using either iron or zinc dust that resulted in the $4(1 H)$-quinolone (aurachin D, 10a) or the corresponding $4(1 H)$-quinolone $N$-oxide (aurachin C, 10b), respectively (Scheme 21). ${ }^{59}$

\section{Conrad-Limpach condensation}
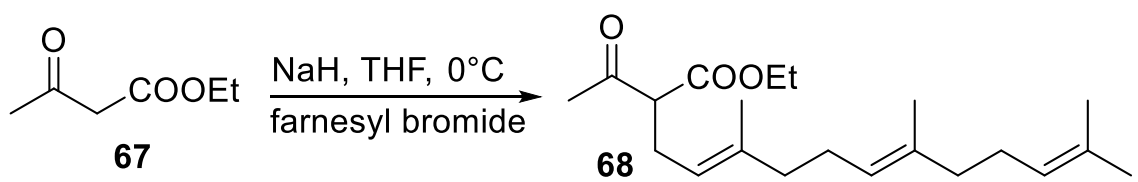

(a) aniline, MS $3 \AA$

PhMe, reflux $\rightarrow$ Aurachin D (10a)

(b) $\mathrm{PhMe}, 250^{\circ} \mathrm{C}$

\section{Reductive cyclisation}<smiles>CC(=O)CC(=O)c1ccccc1[N+](=O)[O-]</smiles>

69

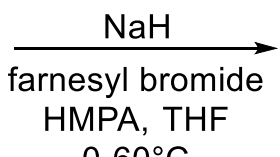

$0-60^{\circ} \mathrm{C}$<smiles>C/C=C\CC/C(C)=C/CC/C(C)=C/CC(C(C)=O)C(=O)c1ccccc1[N+](=O)[O-]</smiles>

Aurachin D (10a)

\section{Selected examples}<smiles>CC(C)=CCC/C(C)=C/CC/C(C)=C/Cc1c(C)[nH]c2ccccc2c1=O</smiles><smiles>CC(C)=CCC/C(C)=C/CC/C(C)=C/Cc1c(C)n(O)c2ccccc2c1=O</smiles>

Scheme 21. Synthesis of aurachins D and C via Conrad-Limpach and a reductive cyclization strategy.

\section{Conclusions}

Bacterial 2-alkyl-4(1H)-quinolones are secondary metabolites that play an important role as quorum sensing signals and in the interaction between microbial species. Since their discovery and first isolation from Pseudomonas species, these quinolones have attracted great interest in their synthesis due to their diverse bioactivity, including antibacterial, antifungal, anti-malarial and anti-inflammatory activity. In this review, we have described the standard strategies as well as the most recent developments in the synthesis of microbial $4(1 H)$-quinolones, which have been divided into different subcategories according to their structural diversity. These strategies include many methods of synthesis ranging from traditional cyclization (Conrad-Limpach and Camps) to metal-catalyzed cyclization ( $\mathrm{Cu}$ - and Au-catalyzed), and C-C cross coupling reactions (SuzukiMiyaura and Sonogashira). Efficient synthetic methods have given access to this important group of microbial metabolites and enable more comprehensive studies of their biological roles and activities in quorum sensing, as virulence factors, and as antimicrobials. These methods will also inspire the synthesis of novel natural product-derived compounds with improved activity or selectivity for a relevant target species. 


\section{Acknowledgements}

We gratefully acknowledge funding by the Emmy Noether program of the Deutsche Forschungsgemeinschaft (DFG), EU FP7 Marie Curie Zukunftskolleg Incoming Fellowship Program - University of Konstanz grant no. 291784, SFB969 project C06, and Konstanz Research School Chemical Biology (KoRS-CB).

\section{References}

1. Lepine, F., Milot, S., Deziel, E., He, J., Rahme, L. G., J. Am. Soc. Mass. Spectrom. 2004, 15, $862-869$. https://doi.org/10.1016/i.jasms.2004.02.012

2. Kawada, M., Inoue, H., Ohba, S., Hatano, M., Amemiya, M., Hayashi, C., Usami, I., Abe, H., Watanabe, T., Kinoshita, N., Igarashi, M., Masuda, T., Ikeda, D., Nomoto, A., J. Antibiot. 2013, 66, 543-548. https://doi.org/10.1038/ja.2013.42

3. Dekker, K. A., Inagaki, T., Gootz, T. D., Huang, L. H., Kojima, Y., Kohlbrenner, W. E., Matsunaga, Y., McGuirk, P. R., Nomura, E., Sakakibara, T., Sakemi, S., Suzuki, Y., Yamauchi, Y., Kojima, N., J. Antibiot. 1998, 51, 145-152. https://doi.org/10.7164/antibiotics.51.145

4. Nachtigall, J., Schneider, K., Nicholson, G., Goodfellow, M., Zinecker, H., Imhoff, J. F., Süssmuth, R. D., Fiedler, H. P., J. Antibiot. 2010, 63, 567-569.

https://doi.org/10.1038/ja.2010.79

5. Kunze, B., Höfle, G., Reichenbach, H., J. Antibiot. 1987, 40, 258-265. https://doi.org/10.7164/antibiotics.40.258

6. Saalim, M., Villegas-Moreno, J., Clark, B. R., Molecules 2020, 25, 5689. https://doi.org/10.3390/molecules25235689

7. Lightbown, J. W., Nature 1950, 166, 356-357.

https://doi.org/10.1038/166356b0

8. Cornforth, J. W., James, A. T., Biochem. J. 1956, 63, 124-130. https://doi.org/10.1042/bj0630124

9. Lightbown, J. W., Jackson, F. L., Biochem. J. 1956, 63, 130-137. https://doi.org/10.1042/bj0630130

10. Lightbown, J. W., Jackson, F. L., Biochem. J. 1954, 58, xlix.

11. Witzgall, F., Depke, T., Hoffmann, M., Empting, M., Brönstrup, M., Müller, R., Blankenfeldt, W., ChemBioChem 2018, 19, 1531-1544. https://doi.org/10.1002/cbic.201800153

12. Diggle, S. P., Matthijs, S., Wright, V. J., Fletcher, M. P., Chhabra, S. R., Lamont, I. L., Kong, X., Hider, R. C., Cornelis, P., Camara, M., Williams, P., Chem. Biol. 2007, 14, 87-96. https://doi.org/10.1016/i.chembiol.2006.11.014

13. Machan, Z. A., Taylor, G. W., Pitt, T. L., Cole, P. J., Wilson, R., J. Antimicrob. Chemother. 1992, 30, 615623.

https://doi.org/10.1093/jac/30.5.615

14. Huse, H., Whiteley, M., Chem. Rev. 2011, 111, 152-159. https://doi.org/10.1021/cr100063u

15. McGrath, S., Wade, D. S., Pesci, E. C., FEMS Microbiol. Lett. 2004, 230, 27-34. https://doi.org/10.1016/S0378-1097(03)00849-8

16. Schuster, M., Greenberg, E. P., Int. J. Med. Microbiol. 2006, 296, 73-81. https://doi.org/10.1016/i.ijmm.2006.01.036 
17. Kim, K., Kim, Y. U., Koh, B. H., Hwang, S. S., Kim, S. H., Lepine, F., Cho, Y. H., Lee, G. R., Immunology 2010, 129, 578-588.

https://doi.org/10.1111/i.1365-2567.2009.03160.x

18. Hooi, D. S., Bycroft, B. W., Chhabra, S. R., Williams, P., Pritchard, D. I., Infect. Immun. 2004, 72, 64636470.

https://doi.org/10.1128/IAI.72.11.6463-6470.2004

19. Reen, F. J., Mooij, M. J., Holcombe, L. J., McSweeney, C. M., McGlacken, G. P., Morrissey, J. P., O'Gara, F., FEMS Microbiol. Ecol. 2011, 77, 413-428. https://doi.org/10.1111/i.1574-6941.2011.01121.x

20. Szamosvári, D., Schuhmacher, T., Hauck, C. R., Böttcher, T., Chem. Sci. 2019, 10, 6624-6628. https://doi.org/10.1039/c9sc01090d

21. Szamosvári, D., Böttcher, T., Synlett 2018, 29, 542-547. https://doi.org/10.1055/s-0036-1591913

22. Coulon, P. M. L., Groleau, M. C., Deziel, E., Front. Cell Infect. Microbiol. 2019, 9, 33. https://doi.org/10.3389/fcimb.2019.00033

23. Szamosvári, D., Böttcher, T., Angew. Chem. Int. Ed. Engl. 2017, 56, 7271-7275. https://doi.org/10.1002/anie.201702944

24. Szamosvári, D., Prothiwa, M., Dieterich, C. L., Böttcher, T., Chem. Commun. 2020, 56, 6328-6331. https://doi.org/10.1039/d0cc02498h

25. Dubern, J. F., Diggle, S. P., Mol. Biosyst. 2008, 4, 882-888. https://doi.org/10.1039/b803796p

26. da Silva, M. F., Soares, M. S., Fernandes, J. B., Vieria, P. C., Alkaloids Chem. Biol. 2007, 64, $139-214$. https://doi.org/10.1016/s1099-4831(07)64004-8

27. Li, J., Sun, W., Saalim, M., Wei, G., Zaleta-Pinet, D. A., Clark, B. R., J. Nat. Prod. 2020, 83, $2294-2298$. https://doi.org/10.1021/acs.jnatprod.0c00026

28. Wells, I. C., J. Biol. Chem. 1952, 196, 331-340. https://doi.org/https://doi.org/10.1016/S0021-9258(18)55737-9

29. Reen, F. J., Clarke, S. L., Legendre, C., McSweeney, C. M., Eccles, K. S., Lawrence, S. E., O'Gara, F., McGlacken, G. P., Org. Biomol. Chem. 2012, 10, 8903-8910.

https://doi.org/10.1039/c2ob26823j

30. Thierbach, S., Wienhold, M., Fetzner, S., Hennecke, U., Beilstein J. Org. Chem. 2019, 15, $187-193$. https://doi.org/10.3762/bjoc.15.18

31. Beifuss, U., Ledderhose, S., Synlett 1997, 1997, 313-315. https://doi.org/10.1055/s-1997-758

32. Wu, X., Zheng, L. L., Zhao, L. P., Zhu, C. F., Li, Y. G., Chem. Commun. 2019, 55, 14769-14772. https://doi.org/10.1039/c9cc06652g

33. Singh, S., Nerella, S., Pabbaraja, S., Mehta, G., Org. Lett. 2020, 22, 1575-1579. https://doi.org/10.1021/acs.orglett.0c00172

34. Lohrer, B., Bracher, F., Tetrahedron Lett. 2018, 59, 3632-3635.

https://doi.org/10.1016/j.tetlet.2018.08.062

35. Li, J., Clark, B. R., J. Nat. Prod. 2020, 83, 3181-3190.

https://doi.org/10.1021/acs.jnatprod.0c00865

36. Pesci, E. C., Milbank, J. B., Pearson, J. P., McKnight, S., Kende, A. S., Greenberg, E. P., Iglewski, B. H., Proc. Natl. Acad. Sci. 1999, 96, 11229-11234.

https://doi.org/10.1073/pnas.96.20.11229

37. Morgan Jr., L. R., Schunior, R. J., Boyer, J. H., J. Org. Chem. 1963, 28, 260-261. https://doi.org/10.1021/jo01036a533

38. Hodgkinson, J. T., Galloway, W. R. J. D., Saraf, S., Baxendale, I. R., Ley, S. V., Ladlow, M., Welch, M., Spring, D. R., Org. Biomol. Chem. 2011, 9, 57-61. https://doi.org/10.1039/COOB00652A 
39. Szamosvári, D., Reichle, F. V., Jureschi, M., Böttcher, T., Chem. Commun. 2016, 52, 13440-13443 https://doi.org/10.1039/C6CC06295D

40. Behrman, E. J., Kiser, R. L., Garas, W. F., Behrman, E. C., Pitt, B. M., J. Chem. Research 1995, 164-165.

41. Hradil, P., Hlavac, J., Lemr, K., J. Heterocyclic Chem. 1999, 36, 141-144. https://doi.org/10.1002/ihet.5570360121

42. Ilangovan, A., Fletcher, M., Rampioni, G., Pustelny, C., Rumbaugh, K., Heeb, S., Camara, M., Truman, A., Chhabra, S. R., Emsley, J., Williams, P., PLoS Pathog. 2013, 9, e1003508. https://doi.org/10.1371/journal.ppat.1003508

43. Hradil, P., Grepl, M., Hlavac, J., Soural, M., Malon, M., Bertolasi, V., J. Org. Chem. 2006, 71, 819-822. https://doi.org/10.1021/jo051303k

44. Hodgkinson, J. T., Galloway, W. R. J. D., Welch, M., Spring, D. R., Nat. Protoc. 2012, 7, 1184-1192. https://doi.org/10.1038/nprot.2012.054

45. Hodgkinson, J., Bowden, S. D., Galloway, W. R. J. D., Spring, D. R., Welch, M., J. Bacteriol. 2010, 192, 3833-3837.

https://doi.org/10.1128/JB.00081-10

46. Hegewald, J., Gross, U., Bohne, W., Mol. Biochem. Parasitol. 2013, 190, 6-15. https://doi.org/10.1016/i.molbiopara.2013.05.008

47. Szamosvári, D., Sylvester, K., Schmid, P., Lu, K. Y., Derbyshire, E. R., Böttcher, T., Chem. Commun. 2019, 55, 7009-7012.

https://doi.org/10.1039/c9cc01689a

48. Hazan, R., Que, Y. A., Maura, D., Strobel, B., Majcherczyk, P. A., Hopper, L. R., Wilbur, D. J., Hreha, T. N., Barquera, B., Rahme, L. G., Curr. Biol. 2016, 26, 195-206.

https://doi.org/10.1016/i.cub.2015.11.056

49. Tietze, L. F., Ma, L., Heterocycles 2010, 82, 377-396

https://doi.org/10.3987/COM-10-S(E)9

50. Woschek, A., Mahout, M., Mereiter, K., Hammerschmidt, F., Synthesis 2007, 1517-1522. https://doi.org/10.1055/s-2007-966020

51. Chapalain, A., Groleau, M. C., Le Guillouzer, S., Miomandre, A., Vial, L., Milot, S., Deziel, E., Front. Microbiol. 2017, 8, 1021. https://doi.org/10.3389/fmicb.2017.01021

52. Piochon, M., Coulon, P. M. L., Caulet, A., Groleau, M. C., Deziel, E., Gauthier, C., J. Nat. Prod. 2020, 83, 2145-2154.

https://doi.org/10.1021/acs.jnatprod.0c00171

53. Salvaggio, F., Hodgkinson, J. T., Carro, L., Geddis, S. M., Galloway, W. R. J. D., Welch, M., Spring, D. R., Eur. J. Org. Chem. 2016, 2016, 434-437.

https://doi.org/10.1002/ejoc. 201501400

54. Geddis, S. M., Carro, L., Hodgkinson, J. T., Spring, D. R., Eur. J. Org. Chem. 2016, 2016, 5799-5802. https://doi.org/10.1002/ejoc.201601195

55. Geddis, S. M., Coroama, T., Forrest, S., Hodgkinson, J. T., Welch, M., Spring, D. R., Beilstein J. Org. Chem. 2018, 14, 2680-2688.

https://doi.org/10.3762/bjoc.14.245

56. Abe, H., Kawada, M., Inoue, H., Ohba, S., Nomoto, A., Watanabe, T., Shibasaki, M., Org. Lett. 2013, 15, 2124-2127. https://doi.org/10.1021/ol400587a

57. Pistorius, D., Li, Y., Sandmann, A., Müller, R., Mol. Biosyst. 2011, 7, 3308-3315. https://doi.org/10.1039/c1mb05328k

58. Li, X. W., Herrmann, J., Zang, Y., Grellier, P., Prado, S., Müller, R., Nay, B., Beilstein J. Org. Chem. 2013, 9, 1551-1558. 


\section{https://doi.org/10.3762/bjoc.9.176}

59. Enomoto, M., Kitagawa, W., Yasutake, Y., Shimizu, H., Biosci. Biotechnol. Biochem. 2014, 78, 13241327. https://doi.org/10.1080/09168451.2014.918494

\section{Authors' Biographies}

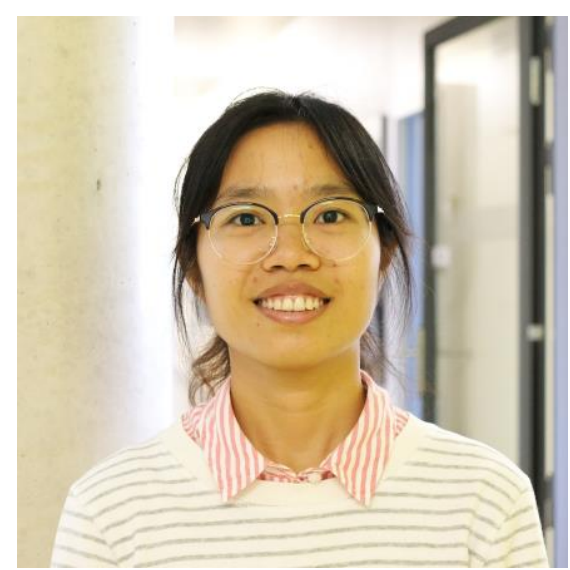

Thi Hong Nhung Nguyen received her M.Sc. in Bioorganic Chemistry from the Nagoya University in 2018, where she worked in the lab of Prof. Hiroshi Abe. In 2018, she joined the group of Prof. Thomas Böttcher at the University of Konstanz for her Ph.D. Her research interest is investigating the bioactivity of $4(1 H)$ quinolones and their synthetic derivatives against pathogenic bacteria.

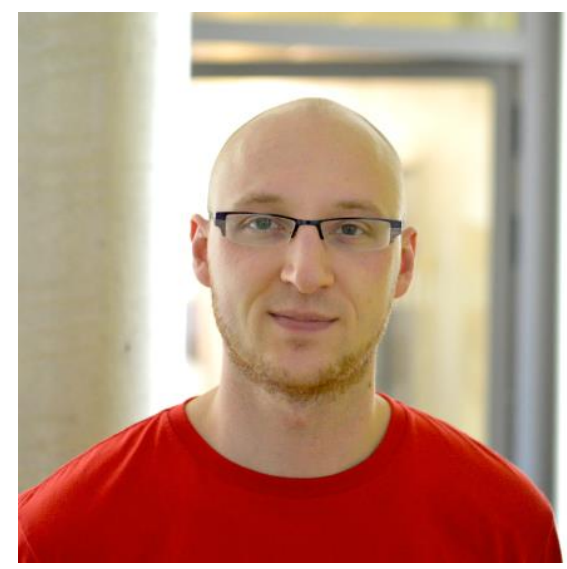

Dávid Szamosvári studied Biochemistry and Chemical Biology at the Friedrich Schiller University (FSU) of Jena and received his M.Sc. in 2014, where he worked in the Biosynthesis/NMR group of Dr. Bernd Schneider at the Max-Planck-Institute for Chemical Ecology on the identification of plant pigments. For his Ph.D., he joined the lab of Prof. Thomas Böttcher at the University of Konstanz in 2015 with a scholarship from the Konstanz Research School Chemical Biology where he investigated the bioactivity of natural $4(1 H)$-quinolones from bacteria and their synthetic derivatives against human pathogens. For his postdoctoral research, he joined the groups of Prof. Ramnik Xavier and Prof. Stuart Schreiber at the Broad Institute in Boston in 2020 on a Feodor Lynen Research Fellowship from the Humboldt Foundation. His current focus lies on the identification and synthesis of bacteria-derived molecules involved in autoimmune regulation. 


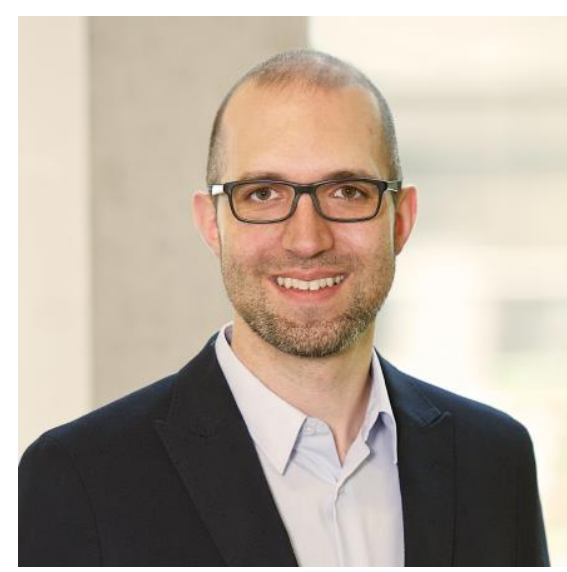

Thomas Böttcher studied chemistry and biochemistry at the Ludwig Maximilian University (LMU) of Munich. In 2009, he completed his Ph.D. at the LMU in the group of Prof. Stephan Sieber supported by a fellowship of the German Academic Scholarship Foundation. After a short postdoctoral stint at the Technical University of Munich, he co-founded the startup company AVIRU GmbH for preclinical drug-development. In 2011, he moved to Boston for postdoctoral research in the laboratory of Prof. Jon Clardy at Harvard Medical School on a Leopoldina Research Fellowship. In 2014, he started his independent research career at the University of Konstanz where he led an Emmy Noether research group and was a research fellow of the Zukunftskolleg. Since 2020, he is a full professor of Microbial Biochemistry, bridging the Institute of Biological Chemistry and the Department of Microbiology and Ecosystem Science at the University of Vienna. He received the ManfredFuchs-Prize 2019 of the Heidelberg Academy of Sciences and Humanities and an ERC Consolidator Grant in 2020. The research interests of his group include microbial secondary metabolites, customized antibiotics, as well as chemical modulators of bacterial behavior and synthetic inhibitors of virulence. 